http://www.sttpb.ac.id/e-journal/index.php/kurios

\title{
Studi Penciptaan Menurut Kitab Kejadian 1:1-31
}

\author{
Bernike Sihombing \\ Sekolah Tinggi Teologi Pelita Bangsa Jakarta
}

\begin{abstract}
Abstrak
Artikel ini membahas Kejadian 1:1-31, tentang penciptaan Allah terhadap segala yang ada, misalnya benda-benda yang diangkasa, hewan dan termasuk penciptaan manusia yang ada di bumi. Segala sesuatu ada bukan sendirinya ada tetapi ada penciptanya. Melalui pengenalan terhadap Kejadian 1:1-31 dapat dijadikan satu ilmu asal mula segala sesuatu yang ada, sehingga umat dikuatkan pada kebenaran bahwa ada yang telah menciptakan langit dan bumi dan segala ini yaitu Tuhan.
\end{abstract}

Kata Kunci: Kejadian; penciptaan; pada mulanya; Perjanjian Lama

\section{Pendahuluan}

Langit dan bumi ada bukan sendirinya ada tetapi ada penciptanya. Penciptaan langit dan bumi beserta isinya menjadi diskusi bukan sesuatu yang baru seperti yang terjadi pada kaum awam, mahasiswa, sarjana, kaum liberal dan Atheis. Masing-masing memberikan klaimnya sehingga dalam diskusi itu memunculkan ragam presepsi. Umumnya pada sarjana teologi sepakat tidak terlalu focus ingin mengetahui berapa usia langit dan bumi setelah dicipta, dan kapan penciptaan itu Allah lakukan. Jika ditinjau pun melalui penanggalannya berdasarkan catatan catatan yang ada sulit untuk mendapatkan berapa usia langit dan bumi dan kapan Allah ciptakan. Meski tidak ada ayat dalam Alkitab yang menjelaskan dengan tepat namun para sarjana teologi percaya bahwa langit dan bumi ada penciptanya.

Banyak penafsir tempo dulu baik dari kalangan teologi maupun non teologi mencoba memprediksi usia langit dan bumi dengan alat prediksi 2 Petrus 3:8, Akan tetapi, saudara-saudaraku yang kekasih, yang satu ini tidak boleh kamu lupakan, yaitu, bahwa di hadapan Tuhan satu hari sama seperti seribu tahun dan seribu tahun sama seperti satu hari (II Pet.3:8). Berdasarkan ayat di atas para penafsir memunculkan tiori sebagai berikut: Pertama, menyebutkan bahwa langit dan bumi ada dengan usia 12.000 
tahun dengan berdasarkan pada perhitungan Adam hingga Nuh selama 2000 tahun, dari Nuh hingga awal tahun Masehi 2000 tahun dan awal tahun Masehi hingga tahun Millenium 2000 tahun sehingga jumlah 6000 tahun. Jadi perhitungannya: $6000+6000$ $+14=12014$ tahun.

Penafsir memberi ragam pandangan usia langit dan bumi sejak diciptakan, masing-masing menyuguhkan teori-teori yang umumnya berdasarkan pada 2 Petrus 3:8. Perhitungan itu dilakukan secara kolektif bahwa usia ciptaan itu, Pertama: berkisar 6000 tahun dengan perhitungan hari dalam penciptaan. Misalnya: Dikalangan teolog tempo dulu perhitungan itu telah umum dimengerti baik oleh orang Yahudi maupun oleh orang Kristen yang percaya sepanjang sejarah, hal itu telah diterima hampir secara universal diantara orang-orang yang percaya sampai abad kesembilan belas. Akhirnya dikemudian dari para penafsir lain mencoba mengklarifikasi kembali dan mengatakan bahwa pemahaman bahwa usia langit dan bumi berusia 6000 tahun adalah penafsiran secara harfiah saja dan hal itu hanya untuk mengaburkan isi Alkitab.

Para pelajar Alkitab telah berabad-abad mencoba mempelajari kronologis penciptaan langit dan bumi, berusaha menggunakan ayat-ayat dalam Alkitab untuk merekonstruksi suatu kronologi langit dan bumi, namun sangat sulit menemukan sudah berapa tahun usia langit dan bumi yang kita diami saat ini. Des Vignolles, dari Royal Society of Berlin (1738), mengatakan bahwa penciptaan langit dan bumi berkisar antara tahun 3500 sampai tahun 7000 Sebelum Masehi. Beda lagi dengan seorang Uskup Agung bernama James Ussher (1581-1656), dari Irlandia Utara, yang mengatakan Penciptaan langit dan bumi terjadi sekitar tahun 4004 S.M. Ragam dan perbedaan penafsiran adalah sesuatu yang wajar dan bukti-bukti seperti yang diutarakan di atas janganlah dijadikan satu doktrin penanggalan tepat terhadap penciptaan langit dan bumi. Perbedaan penafsiran sangat nyata, apakah ratusan juta tahun, ribuan tahun atau jutaan tahun itu sama saja. Pandangan-pandangan semua itu dapat dijadikan menjadi satu pengetahuan bahwa langit dan bumi adalah suatu yang realita, meski usianya tidak diketahui namun ada penciptanya dan hal itu mutlak dipercaya.

\section{Sekilas Pandangan Umum}

Di malam hari yang cerah apabila dilihat ke langit banyak bintang bertaburan menghiasi dengan aneka warna kedap-kedip cahayanya dan itu adalah bagian dari isi alam semesta. Dari sekian banyak jumlah bintang yang ada maka diketahui bahwa langit sangat luas. Astronomi memperkirakan jumlah bintang di alam semesta ada 230 
milliar dan ditambah banyaknya bintang di galaksi Bimasakti yang berjumlah sekitar 300 miliar. Dari banyaknya jumlah bintang yang ada sudah dapat diketahui betapa luasnya ukuran.

Umumnya dalam tulisan yang berkembang dari para Astronomi yang aktif dalam mengkaji asal mula alam semesta, belum dapat mengetahui berapa luasnya langit, sementara asal mula langit dan isinya para Astronomi dan teologi saling mempertahankan argumentnya, bagaimana dan dari mana awalnya ada langit beserta isinya. Para Astronomi tidak dapat memberikan argumentasinya dari mana awalnya langit selain hanya dengan asumsi bahwa semua jagat raya mulai mengembang secara serentak, sementara mengenai isi langit dalam pengkajiannya berawal dari Dentuman besar secara serentak, sehingga percikan Dentuman itu menghasilkan bintang-bintang yang ada hal ini dikenal dalam tiori Bigbang. Sulit dibayangkan bagaimana adanya semua jagat raya yang beragam dapat menyelaraskan awal pengembangan jagat raya itu sendiri secara serentak? Bila demikian seakan ada yang memberikan komando sagar keserentarakan penyelarasan terjadinya alam semesta itu dapat terjadi.

Ada juga bagian dari para astronomi memberi asumsi bahwa jagat raya hanyalah akumulasi materi. Tidak mempunyai awal dan sudah ada sejak waktu tak terbatas dan tidak ada momen "penciptaan", yakni momen ketika alam semesta dan segala isinya muncul. Dari kalangan teologi percaya bahwa langit beserta isinya ada penciptanya yaitu Tuhan. Semua itu ada sejak permulaan yang berawal dari karya Allah melalui Firman-Nya (Kej.1:1, Yoh.1:3).

Akan lebih mudah untuk menghindari tiori bigbang karena tiori itu hanya teori issu. Tiori yang mengatakan langit dan isinya ada karena adanya Dentuman besar itu karena terlupakan matrial Dentuman itu. Jika ada Dentuman sudah tentu ada sebabnya dan dari mana martialnya. Tidak ada salahnya untuk menerima tiori bigbang sebagai pengetahuan karena itu adalah hasil lelah yang telah dilakukan dalam pengkajiannya terhadap langit dan isinya, namun tiori itu diterima hanya sebatas tiori semata.

Melihat begitu luasnya langit dan banyak matrial sebagai isinya yang berjumlah triliunan, semua itu Allah ciptakan secara seketika dan muncul dari ketiadaan. Hanya Tuhan yang mampu melakukan hal itu dan itu harus diakui dan semua itu diciptakan sejak awalnya. Meski sebagian pandangan itu tidak dapat diterima oleh sains itu dapat dimengerti, namun yang harus dipahami jika ada penciptaan maka harus ada penciptanya. 


\section{Musa dan Kitab Kejadian}

Kitab ini terdiri dari 50 pasal dan merupakan kitab pertama dari keseluruhan isi Alkitab. Kitab Kejadian juga dikenal sebagai salah satu dari lima kitab Tora Musa seperti, Kejadian, Keluaran, Imamat, Bilangan dan Ulangan. Kelima kitab tersebut disebukan kitab Tora, ini juga dengan istilah Taurat atau Pentateukh. Meski ada dalam kitab-kitab lain diinformasikan mengenai penciptaan misalnya di dalam kitab Yeremia, itu kutipan dari kitab Tora: Akulah yang menjadikan bumi, manusia dan hewan yang ada di atas muka bumi dengan kekuatan-Ku yang besar dan dengan lengan-Ku yang terentang, dan Aku memberikannya kepada orang yang benar di mata-Ku (Yer.27:5). Musa adalah nabi yang dipercayakan menuliskan apa yang telah diciptakan mengenai adanya jagat raya ini, dan kitab tersebut merupakan sumber informasi sebagai rujukan awal darimana informasi pertama diketahui adanya jagat raya ini.

Musa adalah bangsa Israel nama tersebut diadopsi dari bahasa Ibrani (Mosye) Musa lahir 1527 sM yang berarti diambil dari air. Musa adalah anak Amram bin Kehat dari suku Lewi, anak Yakub bin Ishak, terlahir di Mesir ayahnya bernama Amran dan ibunya bernama Yokhebed. Musa dibesarkan di istana Firaun dan memiliki kakak bernama Miryam dan harum. Musa diangkat menjadi nabi sekitar tahun 1450 SM dan ia ditugaskan untuk membawa Israel keluar dari Mesir. Nama Musa ada disebutkan sebanyak 873 kali dalam 803 ayat dalam 31 buku di Alkitab Terjemahan Baru. Ia memiliki 2 orang anak (Gersom dan Eliezer) dan wafat di Tanah Tih (Gunung Nebo) tahun $1408 \mathrm{sM}$.

Satu-satunya Kitab tertua yang ada memaparkan mengenai darimana segala sesuatu yang ada di jagat raya ini adalah kitab Tora (kitab Kejadian). Di era penulisan kitab Kejadian mengenai penciptaan belum menjadi topic khusus bagi bangsa Israel, karena dimasa itu bangsa Israel hanya bervokus mentaati TUHAN yang mereka sembah. Gagasan mengenai penciptaan baru mendapat penekanan istimewa jauh dikemudian hari teristimewa pada zaman pembuangan (Neh.9:6-31).

Pada mulanya Allah menciptakan langit dan bumi (Kej.1:1). Ayat ini telah diterjemahkan ke dalam Alkitab terjemahan dan saat ini telah beredar dibelahan bumi. Banyak para penafsir telah bergumul telah mencoba menafsir ayat ini digunakan sebagai acuan informasi keberadaan ciptaan yang telah dilakukan Allah. Banyaknya ragam tulisan yang telah dituangkan tidak lain agar pengguna kitab mudah memahami ayat tersebut, untuk memperkaya pengetahuan dan informasi bahwa segala sesuatu 
tidak sendirinya ada tetapi ada penciptanya. Kejadian 1:1 ini juga merupakan ayat pertama sekali ditemukan di dalam kitab PL tepatnya dalam kitab Kejadian dan di dalam bahasa Ibrani dikenal dengan sebutan; kata Bre'siyt yang yang terambil dari kata pertama yaitu dalam Kejadian 1:1.

Kata bre'siyt diterjemahkan pada mulanya judul bahasa Inggris: Genesis berasal dari terjemahan bahasa Yunani Geneseos. Kata Yunani ini terjemahan dari kata Ibrani Toledot (Kej.2:4). Kata ibrani ini berarti keturunan, generasi atau riwayat. Septuaginta (LXX) Mengambil kata geneseos berdasarkan setiap judul dari sepuluh bagian kunci yang menunjukan kepada asal usul yang berbeda judul dari sepuluh bagian kunci ini menyatakan dengan ungkapan he biblos geneseos, daftar keturunan atau buku yang menceritakan tentang generasi. Judul bahasa latin adalah Liber Genesis, kitab tentang kelahiran. Dalam hubungan dengan kitab, Kejadian berarti kitab tentang asal-usul.

Melalui ayat ini ada beberapa pesan penting dapat dijadikan sebagai informasi antara lain: Pertama, adanya penciptaan telah dilakukan Allah. Kedua, ayat ini menjadi pengakuan bagi bangsa Israel sekaligus kebanggaan mereka bahwa dalam kitab Taurat ada dituliskan awal mula segala yang ada. Ketiga, bangsa Israel menyakini penuh bahwa Allah yang telah menciptakan langit dan bumi beserta isinya. Hal ini dimaksud dari pihak Israel sendiri tidak menolak keberadaan ayat itu sebagai informasi penciptaan yang telah diciptakan TUHAN. Keempat, dari berbagai kepercayaan menggunakan sebagai ayat acuan bahwa segala sesuatu ada penciptanya. Kelima, dapat memahami betapa besar dan agung karya TUHAN. Pengenalan terhadap Kejadian 1 merupakan pengetahuan betapa dasyatnya Sang pencipta, menciptakan yang tak dapat dilakukan dan dipikirkan oleh teknologi manusia. Penciptaan itu dari yang tidak ada menjadi ada, artinya ciptaaan itu dari bahan baku yang tidak ada menjadi ada. Keenam, melalui ayat ini awal manusia mengenal adanya Allah (sang Pencipta). Tidak ada yang mampu seperti TUHAN menciptakan segala yang telah ada, dan melalui ciptaan itu dapat diketahui bahwa ada sang Pencipta yang telah mengadakan semua menjadi ada.

\section{Penulisan}

Kejadian 1:1 Ayat ini diperkirakan ditulis Tahun 1440 sebelum Kristus, ditulis menggunakan bahasa Ibrani oleh Musa bersama teamnya dalam perjalanan di Padang gurun ketika Musa membawa umat Israel keluar dari tanah mesir tanah perbudakan. Meski bukti internal tidak ada terdapat dituliskan dalan kitab Kejadian bahwa Musa bersama team menuliskannya, namun banyak saksi memberi dukungan bahwa Musa 
adalah penulisnya. Kejadian termasuk satu kesatuan dari pentateuch (Kel.17:14; 24: 4;34:27; Bil.33:1-2; Ul.31:9; 31:24). Saksi-saksi lain yang juga menguatkan, misalnya Yosua, Daniel, dan Maleakhi (Yos.8:30; Dan.9:11-13, Mal.4:4).

Kesatuan isi, gaya penulisan, sifat pemilihan kata-kata semuanya berbeda dengan tulisan lain yang ada dalam Perjanjian Lama. ${ }^{1}$ Musa dikenal sebagai penulis Pantateuch dengan gaya penulisan mesir. Sedangkan bukti kesaksian External Musa sebagai penulisnya, misalnya arkheologi dan tradisi-tradisi Yahudi. Posisi orang-orang Ibrani dan Kristen sudah sejak lama mengikuti Musa penulisnya.

Tuntutan penulisan Musa cocok dengan pengakuan bahwa ia menggunakan naskah-naskah kuno. Inspirasi ilahi membimbing dia memilih tulisan-tulisannya. Kemungkinan Musa menulis kisah penciptaan itu berasal dari tulisan Abraham atau Nuh atau Henokh. Sesungguhnya tidak ada orang yang lebih mampu menulis kitab itu. Karena Musa dididik dalam segala hikmat orang mesir (Kis.7:22). Sementara kebanyakan orang Ibrani menjadi budak di Mesir. Kemampuan sastranya memungkinkan dia untuk mengumpulkan tradisi-tradisi Israel, mencatat dan menyusun karya itu. Persekutuannya dengan Allah di Horeb dan sepanjang hidupnya sudah mengarahkannya kepada tugas ini. Kesaksian Kristus dan penulis Perjanjian Baru² juga mendukung Musa, penulis kejadian (Yoh.5: 46-47; 1:17; 7:19; Luk.24:44; Kis.28:23).

\section{Pembahasan}

\section{Kejadian. 1:1}

Dalam bahasa Ibrani bunyinya sebagai berikut: “bre'syit bara' elohiym et hasysyamayiym w'et ha'arets". Kata pertama sekali adalah kata bre'syiyt. Bre'syiyt terdiri dari dua kata b - re'syiyt. B (bet) dalam tata bahasa Ibrani adalah preposisi yang berarti di, dalam dan di dalam. Rre'asyit adalah merupakan kata benda dan arti dasarnya: masa, kala, awal, mula. Penggabungan preposisi bet pada kata re'asyiyt menjadi Bre'syiyt, maka B (bet memperjelas keberadaan kata re'asyiyt, yaitu menunjuk pada satu waktu atau ada masa yang tak terbatas. ${ }^{3}$ Pada kedua kata itu, b (bet) lah yang memberi keterangan pada reasyiyt adanya waktu yang tak terbatas itu. Jadi kata Bre'syiyt diartikan: di mulanya..., ini menjelaskan ada satu masa/waktu yang sedang

\footnotetext{
${ }^{1}$ Perjanjian Lama disingkat PL. Penulisan selanjutnya akan menggunakan singkatan.

${ }^{2}$ Perjanjian Baru disingkat PB. Penulisan selanjutnya akan menggunakan singkatan.

3 Masa yang tak terbatas dimaksudkan pada era sebelum ada penghitungan masa, misalnya diluar masa perputaran bumi pada porosnya yang digunakan sebagai tolok ukur menjadi tanda yang menunjukkan masa-masa yang tetap dan hari-hari dan tahun-tahun (band.Ke.1:14).
} 
dibicarakan, dan posisi waktunya tidak ditentukan, namun waktu itu ada sebelum segala sesuatu telah ada diciptakan.

Selanjutnya kata 'bara'makna dasarnya: cipta atau karya. Dalam Bible work versi 6 kata bara'adalah kata kerja Perfect orang ketiga tunggal maskulin, sehingga dapat di artikan sesuai kata kerja yang dimaksud: “dia telah menciptakan”. Melihat dijadikan kata bara sebagai kata kerja pada orang ketiga tunggal dikenali dari vokal yang dikenakan. Apabila dirujuk pada tata bahasa Ibrani, bara bukan kata kerja Perfect, karena vokal yang digunakan pada konsonan pertama dan kedua adalah vokal panjang maka seharusnya adalah kata benda atau kata dasar.

Kata bara digunakan hanya ada 5 kali saja seperti dalam fasal 1:1, 1:27; dua kali disebutkan, Kejadian 2:3, dan yang terakhir dalam Kejadian 5:1. Para Masyoret ${ }^{4}$ memberi vokal pada kedua suku kata ba-ra adalah vokal games + games dan biasanya ciri tersebut dikenakan pada kata benda. Dalam buku-buku tafsir seringkali kata bara yang mendapat vocal pertama dan kedua qames disebutkan sebagai kata kerja tindakan masa lampau yang dikenal dengan qal perfect. Kata 'Bara' bila dibentuk menjadi kata kerja perfect maka sesuai pengartiannya adalah menciptakan, maka vokal yang diberikan pada kata bara adalah qames-patah, maka Kejadian 1:1 dikenali masih bagian dari Kejadian 1:3-5 dan termasuk bagian penciptaan pada hari pertama.

Indikasi kata bara pada kejadian 1:1 bukan kata kerja tetapi kalimat berita adalah, Pertama, ada preposisi bet tertulis kata Bre'syiyt menandai bahwa preposisi tersebut dimaksudkan jauh diluar masa penciptaan hari pertama. Apabila diterjemahkan pada awalnya atau pada mulanya, ini memberi makna bahwa kata bre'syiyt dimaksudkan terjadi sebelum pemisahan siang dalam malam seperti yang terdapat dalam ayat 3-4. Apabila kata bara diartikan sebagai kalimat berita karena menggunakan vokal yang sama pada konsonan pertama dan kedua, maka penggabungan kata Bre'syiyt Bara'yang berarti: Pada Mulanya karya... dengan demikian ayat tersebut bukan kata kerja sehingga tidak akan mendapat benturan dengan ayat-ayat selanjutnya yang menandai dalam hari penciptaan.

Kedua, kata menciptakan yang digunakan pada ayat-ayat selanjutnya seringkali bukan kata bara. Apa bila kata bara dimaksudkan sebagai kata benda maka ayat itu terkesan kalimat berita sehingga tidak berbenturan dengan Kejadian 1:3,5. Alasan kata

\footnotetext{
${ }^{4}$ Yang dimaksud Para Masyoret adalah satu team yang dinamakan ahli bahasa Ibrani kuno yang terdiri 70 orang.
} 
bara diterjemahkan sebagai kata kerja mungkin karena dijadikan sebagai kata pendahuluan mewakili kitab Kejadian. Alasan lainnya kata bara dijadikan sebagai kata kerja perfect karena dalam bentuk bendapun dapat diartikan sama seperti kata kerja perfect, sehingga kata bara dalam Kejadian 1:1 tidak lagi merupakan informasi apa yang telah diciptakan Allah dalam arti sempurna, tentu hal itu akan terbentur sebagaimana yang dimaksud semula sebagai ayat pendahuluan.

Ketiga, Kejadian 1:1 adalah ilham yang diterima oleh Musa, sehingga Musa melaporkan kepada pembacanya bahwa sebelum hari penciptaan Allah ada menjadikan yang tidak ada menjadi ada, itu diluar hari-hari penciptaan, seperti yang dimaksud pada ayat-ayat selanjutnya.

Kemudian setelah kata bara dilanjutkan dengan kata "elohiym" merupakan kata benda jamak diartikan dalam kontek ini berarti Tuhannya yang disembah nabi Musa. Itu dimaksudkan karena Musalah yang telah menerima ilham dari Tuhan dan Musa menuliskannya. Jadi bila digabungkan kata yang telah dibahas seperti yang terdapat dalam Kejadian 1:1 bre'syiyt bara' dalam bentuk benda maka kata tersebut dapat diartikan diawalnya karya Tuhan yang disembah nabi Musa... atau pada mulanya karya Tuhan yang disembah nabi Musa..."

Pengartian kata pada mulanya karya Tuhan... berbicara mewakili seluruh apa yang menjadi pertama sekali yang pernah dilakukan TUHAN dalam karya-Nya diluar masa penciptaan. Dalam hal ini yang menjadi konsentrasi adalah kata bara, artinya kata tersebut harus dibedakan dengan ciptaan lainnya. Makna kata pada mulanya ini berbedanya dengan kata hari pertama seperti yang terdapat pada pasal 5 Dan Tuhan menamai terang itu siang, dan gelap itu malam. Jadilah petang dan jadilah pagi, itulah hari pertama (Kej.1:5).

Seperti yang telah dibahas di atas bahwa kata pada mulanya digunakan dengan kata bre'syiyt sedangan kata hari pertama digunakan dengan kata 'yom 'ehad' yang berarti pertama. Jadi, kata bara' yang terdapat dalam Kejadian 1:1 mengandung satu kreasi sedangkan dalam ayat-ayat lainnya seperti pada Kejadian 1:5 digunakan dengan kata 'yhiy' adalah ucapan/perkataan/Firman.

Kemudian, Kata 'hasysymayim' dari akar kata syamayim, dalam PL yang menggunakan bahasa Ibrani syamtim ada ada dituliskan 236 kali dalam ayat, merupakan kata benda jamak luar biasa, dalam konteks ini diartikan: langit, mengacu pada langit yang luas yang tidak ada batasnya. Sinonimnya adalah alam samudra 
termasuk ruang angkasa (hampa udara) dan disanalah Tuhan akan menempatkan alatalat penerang antara lain seperti matahari dan planet lainnya termasuk bintang-bintang. Dalam PL Alkitab terjemahan kata langit ada disebutkan sebanyak 351 kali dalam ayat. Kata syamayim tidak selalu berarti langit tetapi dapat juga diartikan dengan sorga, karena langit dan surga menggunakan kata yang sama, sehingga dalam mengartikan kata symayim harus diterjemahkan sesuai konteksnya. Dalam Alkitab terjemahan kata langit ada digunakan sebanyak 351 kali dalam ayat, sedangkan sorga ada digunakan sebanyak 95 kali dalam ayat. dengan demikian bila diambil kesimpulam penjelasan di atas, langit dan sorga dalam bahasa Ibrani menggunakan kata yang sama yaitu syamayim.

Dalam konteks ini syamayim bukanlah yang dimaksud sorga tetapi seperti yang telah dijelaskan di atas bahwa syamayim adalah: langit yang luas yang tidak ada batasnya. Apa bila kata syamayim dalam konteks ini dipaksakan dengan arti sorga karena menggunakan kata yang sama, maka harus diartikan bahwa langit yang luas yang tidak ada batasnya adalah milik kepunyaan Allah, Langit adalah takhta-Ku dan bumi adalah tumpuan kaki-Ku (Yes. 66:1).

Selanjutnya kata 'ha'arets' kata tersebut terdiri dari dua kata ha + arets, ha merupakan awalan yang melengkapi maksud kata sebelumnya. Kata "ha" dalam kata tersebut diartikan "itu", ini bukan berbicara sebagai kata tunjuk namun berfungsi sebagai kata penentu sekaligus memberi keterangan sebagai obyek tidak langsung pada kata yang mengikutinya yaitu kata arets yang berarti bumi tanah, wilayah, sekitarnya. Jadi kata ha'arets diterjemahkan dari salah satu makna yang telah disebutkan di atas adalah "bumi itu."

Dalam Alkitab terjemahan kata "Arets" di terjemahkan dengan bumi (earth, land, ground). Meski arets diterjemahkan dengan bumi, bukan berarti yang dimaksud bumi atau tanah, daratan yang saat ini kita diami, melainkan maksudnya ada tempat atau sesuatu tempat yang tidak ada menjadi ada. disanalah Tuhan akan tempatkan seluruh ciptaan misalnya atmosfir galaksi bintang dan lainnya dalam arets itu. Hal ini dikarenakan bumi yang kita diami saat itu belum ciptakan dan akan diciptakan pada hari keempat (ini akan dibahas pada pembahasan ayat 14). 
Seperti yang disebut di atas, ha merupakan awalan dan diterjemahkan dengan arti itu. ${ }^{5}$ Maksud awalan tersebut bukan sebagai kata penunjuk tetapi sebagai kata penentu atau penegas. Adapun alasan ha bukan kata penunjuk dikarenakan dalam bahasa Ibrani ada khusus kata penunjuk itu yaitu ze. Jadi bila diambil satu kesimpulan dari keseluruhan Kejadian 1:1 yang berbunyi: bre'syiyt bara elohiym et hasysyamayiym W'et ha'arets berarti: di awal-awalnya/pada mulanya karya Tuhan adalah langit dan juga sekitarnya, atau pada mulanya karya Tuhan yang disembah nabi Musa adalah langit dan sekitarnya. Juga dapat diartikan: di awal segala yang ada Allah menciptakan dari yang tidak ada menjadi ada.

Yang dimaksud diawal-awalnya dalam bagian ini ada pemisahan dengan masamasa penciptaan seperti yang terdapat pada ayat 2 dan seterusnya, dengan itu hipotesisnya bahwa Kejadian 1:1 dan Kejadian 1:2 ada dua masa.

Pada akhir Kejadian 1:1 ada dibubuhkan silluq, sedangkan di awal anak kalimat Kejadian 1:2 ada kata hubung waw, maka ke 2 tanda baca tersebut memberi keterangan Kejadian 1:1 ada satu peristiwa komplit, sedangkan Kejadian 1:2 adalah berita lanjutan dengan peristiwa yang berbeda. Kejadian 1:1 dan ayat 2 merupakan satu alur cerita namun berbeda peristiwa atau dalam bahasa sederhananya dalam satu cerita dan ada 2 peristiwa.

\section{Kejadian 1:2}

Antara Kejadian 1:1 dan Kejadian 1:2, ada masa yang tidak terbatas, dalam masa yang tak terbatas itu dimungkinkan ada peristiwa yang telah terjadi hingga pada ayat 2 difirmankan Bumi belum berbentuk dan kosong; gelap gulita menutupi samudera raya. Kata yang digunakan wha'arets... yang berarti dan bumi itu. Kata hubung waw memberi keterangan Musa sedang melanjutkan untuk memberitahukan setelah ayat 1 ada peristiwa yang terjadi sehingga itu alasan maka disebutkan: dan bumi itu gelap gulita, dan bumi (sekitarnya) itu berantakan (tidak berbentuk) dan kacau (gelap).

Ada tafsir tempo dulu menjelaskan, peristiwa yang terjadi pada kejadian 1:2 erat hubungannya dengan Yesaya 14:12. Ada sebab musabab terjadinya kekacauan. Ada malaikat yang menantang TUHAN, akibatnya, ia di jatuhkan. Nabi Yesaya menyebutkannya Malaikat itu dengan sindirin dengan Ben-Syakhar (putra fajar) dan di dalam bahasa Latin tradisinya sering disebutkan dengan Lucifer. Dari kalangan teologi

\footnotetext{
${ }^{5}$. Kata ha dapat diartikan juga sebagai kata penentu ini atau itu.
} 
liberal ada sebagian mengatakan kekacauan yang terhadi pada Kejadian 1:2 tidak memiliki hubungan dengan Yesaya 14:12. Karena yang dimaksud dalam Yesaya 14:12 mengarah pada raja Asyur yang memiliki keinginan yang sama seperti Ben-syakhar. ${ }^{6}$

Seperti yang telah dijelaskan di atas, dalam Kejadian 1:2 disebutkan dan bumi itu itu kacau, berantakan, tidak tertata ( baca: hayta tohu), maka Roh Allah melayang-layang di atas ciptaan itu. Musa menyebutkan dengan: melayang-layang di atas permukaan air. Ayat yang digunakan nyal-pney hammayim, makna hurufiahnya yang berarti di atas pemukaan air, Memang sangat sulit memahami apabila anak kalimat tersebut diartikan sesuai bahasa kamus. Pertanyaannya: air mana yang dimaksud dalam ayat itu sementara air di masa itu belum ada.

Sebagai kesimpulan awal bahwa yang dimaksud air dalam ayat tersebut bukanlah air sebagaimana yang sering kita konsumsi atau digunakan untuk membersihkan tubuh (mandi). Ilmuwan bernama Philip Ball, menuliskan dalam bukunya yang berjudul Water and life, mengatakan Air dalam rumus kimianya $\mathrm{H}_{2} \mathrm{O}$ adalah senyawa dan penting bagi semua bentuk kehidupan yang diketahui sampai saat ini $\mathrm{H}_{2} \mathrm{O}$ tidak ada diluar atmosfir, dan $\mathrm{H}_{2} \mathrm{O}$ tersebut menutupi hampir 71\% permukaan Bumi. Maka dari maksud itu hammayiym bukanlah dalam rumusan $\mathrm{H}_{2} \mathrm{O}$ karena bumi saat itu belum diciptakan.

Indikasi lain bahwa kata hammayim bukanlah $\mathrm{H}_{2} \mathrm{O}$ karena pada kata tersebut ada ditandai dengan kehadiran maqqep diantara kata Nyal dan Pney yang berarti "ada" diantara, sementara pada kata: hammayim ada artikel ha dibubuhkan sebagai awalan penentu sehingga artikel tersebut membentuk kata mayim menjadi obyek tidak langsung. Dengan pembahasan diatas maka ada satu titik temu memberi keterangan bahwa yang dimaksud air dalam frase tersebut bukanlah $\mathrm{H}_{2} \mathrm{O}$ tetapi merupakan kata kiasan/simbolik yang merujuk ada kehidupan (yang telah dicipta yang tidak ada menjadi ada). Jadi makna Roh Allah melayang-layang di atas permukaan air, Roh Tuhan

\footnotetext{
${ }^{6}$ Kata Ben-syakhar merupakan kata sindirin terhadap malaikat yang dijatuhkan TUHAN karena telah memberontak. Kata itu merupakan bahasa Ibrani seperti yang terdapat dalam Yesaya 14:12. Meski Ben-syakhar. hanya sebutan sindirin tetap ia adalah malaikat yang juga ciptaan TUHAN, karena segala sesuatu yang ada ataupun yang di Surga bukan ada sendirinya tetapi ada penciptanya. Malaikat ada bukan tanpa ada penciptanya tetapi malaikat juga merupakan ciptaan sebagaimana manusia ciptaan TUHAN, karena di dalam Dialah telah diciptakan segala sesuatu, yang ada di sorga dan yang ada di bumi, yang kelihatan dan yang tidak kelihatan, baik singgasana, maupun kerajaan, baik pemerintah, maupun penguasa; segala sesuatu diciptakan oleh Dia dan untuk Dia (Kolose 1:16). Malaikat adalah mahluk sebagaimana manusia dan kemampuannya melebihi manusia, kodratnya berbedanya dengan manusia karena malaikat tidak takluk pada kematian, Namun Engkau telah membuatnya untuk waktu yang singkat sedikit lebih rendah dari pada malaikat-malaikat, dan telah memahkotainya dengan kemuliaan dan hormat (Ibrani 2:7).
} 
hadir (kembali) meninjau kehidupan atau ciptaan yang tidak ada menjadi ada dan ciptaan itu telah (menjadi) gelap gulita/ berantakan/ kacau-balau karena Ben-syakhar karena dijatuhkan dari sorga.

\section{Kejadian 1:3}

Sains memberi pandangan terjadinya terang dijagat raya ini karena adanya matahari. Terjadinya siang dan malam yang dilihat manusia itu karena adanya perputaran bumi pada rotasinya, dan yang searah matahari akan mendapat sinar dan itu akan disebut terang atau siang sedangkan yang tidak dapat sinar akan disebut gelap atau malam. Perputaran bumi pada porosnya hingga menjadikan dua dimensi gelap dan terang dan itulah yang dijadikan pemisah waktu bagi makhluk yang ada di bumi. Meski bumi berputar pada porosnya tanpa ada matahari waktu seakan tidak berjalan, jadi mataharilah yang memberi siang/terang atau malam/gelap maka alat penerang itu yang menjadi penentu adanya siang/terang atau gelap/malam maka alat penerang itu disebutkan dalam bahasa Indonesia mata + hari $=$ matahari.

Jadilah terang." Lalu terang itu jadi (Kej.1:3). Kata yang digunakan adalah 'or. Meski arti kamus kata 'or adalah siang atau terang, namun makna ayat tersebut bukan semakna dengan terjadinya siang dan malam sebagaimana bumi berputar pada porosnya. Adapun alasan-alasannya, pertama, alat penerang di masa itu belum diciptakan, misalnya matahari. Dua, ada ayat sebelumnya yang menjadi latar-belakang mengapa menggunakan kata 'or. Ada peristiwa yang terjadi sehingga menjadikan ciptaan Tuhan yang dimaksud pada ayat di ayat 2 disebutkan tidak berbentuk dan kosong (berantakan).

Sebelum Tuhan menciptakan jagat raya sudah ada kehidupan misalnya adanya masa penciptaan malaikat-malaikat. Karena kejatuhan malaikat itu maka Allah harus menata kembali apa yang pernah diciptakan, ciptaan harus teratur, keteraturan itulah dimaksud kata terang/teratur seperti yang terdapat dalam Kejadian 1:3. Pada kata 'or ada dihadirkan tanda maqqep sehingga kata 'or mendapat arti sebagai obyek tidak langsung. Kehadiran maqqep menjadikan kata tersebut diartikan bukan berarti harus sesuai kamus, tetapi ada makna lain dalam penggunaannya, ini yang dikenal dengan istilah makna sintaksis yang terkandung dalam kata. Senada dengan itu John H. Walton menjelaskan bahwa kata terang yang terdapat dalam Kejadian 1:3 bukanlah berbicara untuk memberitahukan bahwa terang yang dimaksud berasal dari matahari. 
Sedangkan kata kata "la'or" dalam ayat 5 tanpa pembubuhan maqqep,7 sesuai gramatikal Ibrani kata tersebut terdiri dari 3 kata, pertama, lamed sebagai preposisi. Dua, he sebagai kata awalan memiliki vokal qames. Tiga, 'or sebagai kata sifat. Dalam ayat itu tidak dihadirkan awalan he itu karena ada penambahan preposisi sebelum awalan he sehingga awalan he berkonstrak, sementara vokalnya diberikan pada preposisi sehingga kata lha'or menjadi la'or, meski dalam tampilannya tidak dihadirkan awalan he namun dalam terjemahannya makna awalan he tetap dihadirkan, jadi kata la'or di artikan kepada terang itu. Kehadiran he pada kata lha'or membentuk kata or menjadi obyek tidak langsung, jadi kata or (terang) dimungkin adalah kata kiasan atau yang dimaksud pada sesuatu obyek.

Tuhan melihat bahwa terang itu baik, lalu dipisahkan-Nyalah terang itu dari gelap (Kej.1:4), setelah ada penataan kembali pada ciptaan, penataan itulah yang memberi pemisah antara ketidakteraturan (gelap) dengan yang teratur (siang). inilah yang dimaksud dipisahkan-Nyalah terang itu dari gelap. Tuhan tidak menginginkan adanya ketidak-teraturan karena, Pertama: ketidak-teraturan itu tidak baik. Allah tidak menginginkan ada ketidak-teraturan karena ketidak-teraturan itu identik dengan kegelapan/tidak tertata atau tidak bertuan. Dua, Tuhan selalu menginginkan ada keteraturan (bandingkan 1Kor.14:40). Teratur berarti tertata dengan baik/berbentuk, jelas dan terang. Tiga, Tuhan menginginkan ada keteraturan pada ciptaan-Nya apalagi ada rencana besar yang akan Allah lakukan menciptaan mahluk yang sempurna yang kedua (manusia) setelah Malaikat.

Jadilah petang dan jadilah pagi, itulah hari pertama (Kej.1:5b). Kata petang dan pagi berarti ada perubahan waktu. Setelah adanya penataan yang dilakukan Allah atas ketidakteraturan itu, semua menjadi baik (terang/sempurna) itulah yang dilakukan Tuhan sebagai yang pertama. Jadi kata dipisahkan-Nyalah terang itu dari gelap itu berbicara mengenai penataan kembali ciptaan yang telah kacau agar ada keteraturan.

\section{Maksud Hari Dalam Penciptaan}

Hari pertama hari kedua hari ketiga dengan seterusnya yang terdapat dalam kitab kejadian fasal 1 bukan menunjuk hari-hari seperti senin, selasa, rabu dan seterusnya. Kata yang digunakan untuk menujuk pada hari adalah kata "yom" dan makna harafiahnya adalah siang, terang dan waktu. Dengan demikian maksud dari

\footnotetext{
${ }^{7}$ Maqqep bentuknya seperti kata hubung namun fungsinya menjadikan kata yang menggunakannya seperti kata majemuk bila dalam bahasa Indonesia
} 
penulis kitab pada kata hari untuk menunjuk adanya pemisahan waktu antara penciptaan yang satu dengan yang lainnya. Untuk kata petang digunakan kata nyereb dan untuk kata pagi digunakan kata boqer, kedua kata tersebut didahului dengan tanda maqqep yang memberi arti pada kata tersebut tidak dapat diartikan secara harafiah.

Jarak antara hari pertama, kedua dan ketiga hingga seterusnya dapat diartikan menunjuk pada suatu kurun waktu (lih. 2:4; 5:2; Rut 1:1; Maz 50:15; 90:4; Pkh 7:14; Yes 4:2; 11:2; Zak.4:10). Sangat sulit mengetahui berapa durasi yang dibutuhkan antara ciptaan yang satu dengan yang lainnya, hal ini tentu tidak dapat disejajarkan dengan pernyataan satu hari bagi Allah seribu tahun bagi manusia (2Pet.3:8), jika dihubungkan dengan ayat tersebut tentu itu pernyataan berspekulasi karena konteks pada 2 Petrus 3:8 itu berbeda dengan konteks pada kitab Kejadian.

Melihat sulitnya ditentukan berapa durasi antara hari pertama dengan hari kedua dan seterusnya, itu karena teks yang mendukung untuk hal itu tidak dituliskan. Penulis kitab tidak ada hendak memaparkan berapa durasi ciptaan yang satu dengan ciptaan lainnya, tetapi penulis kitab ingin menginformasikan bahwa segala sesuatu yang telah ada bukan sendirinya ada tetapi ada Penciptanya. Jadi, yang dimaksud hari pada ayat penciptaan itu menunjuk pada gaya bahasa yang memberi makna adanya kinerja Tuhan yang memberi pemisahan durasi waktu antara ciptaan yang satu dengan ciptaan yang lainnya.

\section{Teologi}

Maksud kata "hari" dalam Kejadian1:5 adalah: jadwal kinerja Allah yang sempurna Yang dimaksud "hari" dalam ayat-ayat penciptaan itu adalah Schedule = jadwal kinerja Allah yang sempurna dan semua itu telah ditentukan sesuai yang dikehendakinya. Yang terpenting dapat dipahami kata "hari" ada kinerja Allah dalam rencana-Nya untuk mengadakan sesuatu yang tidak menjadi ada dan akhirnya seluruh ciptaan diserahkan pada ciptaan yang teristimewa itu yaitu manusia untuk menjadi kelangsungan hidup.

Allah memiliki kenerja yang baik dan sistematis. Selain dari pada maksud hari adalah schedule pada kata "hari, ada urutan penciptaan segala sesuatu yang telah ada, ini menunjuk bahwa Allah memiliki kenerja yang baik dan sistematis yang perlu diteladani sebagai ciptaan yang tersempurna dari segala ciptaan yang ada.

Allah memiliki kenerja yang teratur. Apa yang telah ada hasil dari ciptaan itu bukan sendirinya ada tetapi ada penciptanya yaitu Tuhan Allah yang. Allah menciptakan 
segalanya segala yang ada bukan suatu kebetulan tetapi semua diciptaan Allah memiliki kenerja yang teratur dan itu sesuai system yang dikehendali Allah. Hal itu dapat dilihat dari hasil apa yang telah ada dari penciptaan itu sempurna adanya, susunan planetplanet atau galaxy yang ada pencahayaan mata hari juga perputaran setiap planet tersebut semua tertata dengan rapi.

Daftar urutan Penciptaan adalah sebagai berikut: Hari pertama ('ekhat); Hari kedua (Syttayim); Hari ketiga (Syalosy); Hari keempat ('adbbay); Hari kelima (khamesy); Hari ke enam (syesy); Hari ketujuh (syebay)

\section{Kejadian 1:6-8}

Jadilah cakrawala di tengah segala air untuk memisahkan air dari air (Kej.1:6). Bahasa Ibrani cakrawala adalah raqiya, dalam kamus bahasa Indonesia cakrawala diartikan (1) lengkung langit; (2) langit (tempat bintang-bintang); (3) peredaran bintang di langit (kerap pula berarti sebagai bintang di langit); (4) kaki langit; tepi langit.

Pembahasan sebelumnya sudah dijelaskan ciptaan itu terjadi kekacauan dampak Ben-syakhar dibuang dari surga, maka Tuhan menata kembali yang tak beraturan itu dengan misahkan yang tidak teratur dan teratur lalu Tuhan menciptakan cakrawala. Ini informasi mengenai penataan tempat dan batas dimana ciptaan yang lainnya akan ditempatkan, agar ciptaan yang satu dengan yang lainnya tertata dengan baik sesuai penempatannya. Analoginya ibarat tangan seorang pelukis sedang membuat lukisan halus (kisi-kisi) di atas kampasnya sebagai bayangan gambar sesuatu yang akan dilukiskan. Hal itu sejajar dengan makna kamus yang disebutkan diatas bahwa cakrawala adalah langit (tempat bintang-bintang), peredaran bintang di langit.

Maka Allah menjadikan cakrawala dan Ia memisahkan air yang ada di bawah cakrawala itu dari air yang ada di atasnya (Kej.1:7). Cakrawala yang diciptakan Tuhan yang dimaksud dalam ayat ini bukanlah sama dengan langit, meski cakrawala dan langit adalah kata benda yang sama, namun kedua kata tersebut menggunakan dua kata yang berbeda. Cakrawalah disebut raqiyay yang juga merupakan langit namun mengarah pada langit yang terbatas atau dikenal dengan atmosfir. Sedangkan untuk langit yang tanpa batas disebut syamayim. Untuk kata "air" telah dibahas di atas adalah kehidupan yang telah diciptakan Allah yang belum pernah ada menjadi ada (creatio ex nihilo).

Allah membuat satu pemisahan kehidupan yang ada. Allah menciptakan cakrawala ditengah ciptaan yang ada, disanalah ditempatkan bintang-bintang atau 
tempat peredaran bintang-bintang di langit. Bila dikolaborasikan dengan temuan para astronomi dengan jumlah bintang yang ada 70.000.000.000.000.000.000.000 bintang, atau 230 milliar kali banyaknya bintang di galaksi Bimasakti yang berjumlah sekitar 300 miliar, namun semua bintang yang ada itu dalam posisi teratur. Dengan jumlah bintang yang ada miliaran jumlahnya dilangit namun penempatannya teratur hal itu tentu bukan suatu kebetulan tetapi Tuhan telah menempatkannya dengan baik.

\section{Kejadian 1:9-13}

Hendaklah segala air yang di bawah langit berkumpul pada satu tempat, sehingga kelihatan yang kering (Kej.1:9). Firman ini memberitahukan bahwa Allah memberi karakter atau sifat pada air dan darat, air memililiki cirri yang akan selalu mencari tempat yang paling rendah sehingga pada akhirnya air itu akan bersatu pada satu titik yang bermuara pada laut. Sedangkan darat adalah bentuk banding dari kata air atau basah, sehingga tempat yang tidak berair itu akan disebut darat, ini menandai untuk persiapan ciptaan lainnya, pada gilirannya seperti aya selanjutnya. Lalu Allah menamai yang kering itu darat, dan kumpulan air itu dinamai-Nya laut (Kej. 1:10). Apa yang difirmankan Allah tidaklah bertentangan dengan hukum alam yang ada khususnya sifat air. Pada kenyataannya air sifatnya mengalir selalu mencari tempat yang paling rendah.

Kejadian 1:11 Berfirmanlah Allah: "Hendaklah tanah menumbuhkan tunas-tunas muda, tumbuh-tumbuhan yang berbiji, segala jenis pohon buah-buahan yang menghasilkan buah yang berbiji, supaya ada tumbuh-tumbuhan di bumi." Dan jadilah demikian. 1:12 Tanah itu menumbuhkan tunas-tunas muda, segala jenis tumbuhtumbuhan yang berbiji dan segala jenis pohon-pohonan yang menghasilkan buah yang berbiji. Allah melihat bahwa semuanya itu baik. Kejadian 1:11-12 merupakan ayat yang memiliki satu satuan untuk menyatakan dimana ada air disana ada kehidupan (baca: tunas) baik di atas daratan maupun di dalam lautan. Ayat di atas disebutkan bahwa Allah berfirman agar tanah menumbuhkan tunas-tunas muda, tumbuh-tumbuhan yang berbiji, segala jenis pohon buah-buahan yang menghasilkan buah yang berbiji, supaya ada tumbuh-tumbuhan di bumi. Semua yang ada itu bukan sendirinya ada, tetapi ada yang menciptakannya, semua itu akan menjadi kebutuhan manusia yang akan di ciptakan Tuhan untuk dikonsumsi untuk kelansungan hidup, bagian dari dekorasi keindahan alam juga akan menjadi siklus oksigen yang akan dibutuhkan oleh mahluk hidup lainnya yang akan diciptakan Tuhan. 


\section{Kejadian 1:14}

Jadilah benda-benda penerang pada cakrawala untuk memisahkan siang dari malam, demikian bunyi Firman Tuhan yang terdapat dalam Kejadian 1:14a. Tuhan memberitahukan asal mula adanya alat penerang yang disebutkan matahari. Setiap orang pasti mudah memahami yang dimaksud alat penerang untuk pemisah siang dan malam dan setiap hari muncul jika tidak ada mendung, dan jika ada teriknya terasa sangat panas dapat membakar kulit ari dan ia bersembunyi apabila di malam hari.

Meski kata syemesy yang berarti matahari, tidak ada disebutkan dalam ayat tersebut namun dari karacternya adalah alat penerang sebagai pemisah siang dan malam maka dapat diketahui bahwa kata m'orot birqiya diartikan adalah matahari.

Bentuk kata m'orotadalah jamak, maka benda-benda yang dimaksud sebagai alat penerang diciptakan bukanlah hanya satu saja. Bila dikolaborasikan dengan temuan para astronomi bahwa alat penerang yang dimaksud adalah matahari dan merupakan salah satu bintang dari triliunan jumlahnya di jagat raya, maka singkron dengan apa yang tertulis dalam Alkitab bahwa Tuhan menciptakan alat-alat penerang dalam bentuk jamak yang berarti bukan hanya matahari saja. Matahari adalah bintang yang paling terdekat dari permukaan bumi. Diperkirakan jaraknya sekitar 149,680,000 kilometer bila dibandingkan dengan bintang-bintang yang jumlahnya triliunan di jagat raya. Bila jarak yang disebutkan di atas adalah jarak terdekat maka sudah dapat dibayangkan betapa jauh jarak bintang yang lainnya dengan bumi, maka diketahui betapa luasnya jagat raya atau yang disebut syamayim (langit) yang telah diciptakan oleh Tuhan.

\section{Bumi Dicipta Pada Hari Ke-4}

Banyak tulisan yang telah dituangkan dalam lembaran-lembaran hingga menjadi bacaan, dan dijadikan sebagai satu informasi bahwa bumi diciptakan Tuhan disebutkan sesuai Kejadian 1:1, karena dalam ayat itu ada disebutkan kata arets yang berarti bumi. Dari sekian banyak arti dari kata Arets diambil satu dari makna kata tersebut yaitu kata bumi. Pada akhirnya kata itulah dimaksudkan sebagai informasi mengenai awal penciptaan bumi. Apalagi dalam Alkitab terjemahan sangat jelas disebutkan dengan kata "bumi" (Pada mulanya Allah menciptakan langit dan bumi (Kej.1:1). Tafsiran itu sangat bertentangan dengan ilmu pengetahuan. Ironisnya jika hal itu tidak diterima sebagai informasi maka seringkali pada akhirnya memberikan pertanyaan, apakah anda lebih percaya pada Alkitab atau ilmu pengetahuan? 
Sulit membayangkan jika bumi diciptakan lebih dulu dari semua benda-benda langit yang ada misalnya bintang-bintang. Bumi yang kita diami saat ini bukanlah diciptakan sesuai pada kejadian 1:1 tetapi diciptakan pada hari ke-4 sebagaimana yang terdapat dalam Kejadian 1:14 yang disebutkan alat-alat penerang. Alat-alat penerang itu adalah salah satu bintang yang berjumlah milliaran dan pada gilirannya diketahui salah satunya adalah matahari yang memiliki 8 planet dan bumi adalah planet ke-3. Jadi, ketika Allah menciptakan alat-alat penerang, saat itu juga bumi diciptakan karena bumi, markurius vebus dan lannya adalah bagian dari planet dari alat penerang itu.

\section{Bumi Adalah Planet Salah Satu Bintang}

Alat penerang yang dimaksud dalam Kejadian 1:14 adalah bintang yang terdekat dari permukaan bumi, itulah yang disebutkan oleh penduduk bumi adalah matahari yang memiliki delapan planet. Menurut IAU (Persatuan Astronomi Internasional) sesuai dengan defenisi yang baru, matahari terbilang salah satu bintang yang jumlahnya triliunan di jagat raya, bintang tersebut memiliki planet-planet sebagai berikut, Merkurius, Venus, Bumi, Mars, Yupiter, Saturnus, Uranus dan Neptunus. Orang Yunani memiliki nama sendiri untuk masing-masing planet Pada abad ke-6 SM, bangsa Yunani memberi nama Stilbon (cemerlang) untuk Planet Merkurius, Pyoroeis (berapi) untuk Mars, Phaethon (berkilau) untuk Jupiter, Phainon (Bersinar) untuk Saturnus. Khusus planet Venus memiliki dua nama yaitu Hesperos (bintang sore) dan Phosphoros (pembawa cahaya) dan di dalam bahasa latin di sebut Lucifer. Hal ini terjadi karena planet Venus yang muncul di pagi dan di sore hari dianggap sebagai dua objek yang berbeda.

Nama-nama planet matahari diambil dari nama-nama dewa-dewa dalam mitologi Yunani dan planet-planet tersebut dinamai dengan nama yang dikenal hingga sekarang. Filsuf yang bernama Aristoteles yang hidup pada abad ke - 4 SM ambil bagian memberikan nama planet tersebut. Ketika ia memperkenalkan nama-nama dewa dalam mitologi misalnya Hermes dan nama itu menjadi nama untuk Merkurius, sedangkan Ares untuk nama planet Mars, dan Zeus untuk Jupiter, sementara Kronos untuk Saturnus dan Aphodite untuk planet Venus. Sedangkan yang lainnya diberi nama Uranus yang merupakan nama dewa Yunani. Dinamakan Uranus karena Uranus adalah ayah dari Kronos (Saturnus) dan untuk Planet ke-8 diberi nama Neptunus yang dikenal dengan dewa laut dalam mitologi Romawi. 


\section{Kejadian 1:15-18}

Perputaran bumi pada porosnya inilah alasan adanya siang dan malam, ketika permukaan bumi disinari matahari itulah yang disebut siang sedang permukaan bumi dibalik belahan yang tidak tersinari matahari itulah yang disebut malam, dan periode peredaran harian matahari ada 24 jam. Ada siang ada malam, kedua itu terbagi dua dengan masing-masing ada 12 jam. Menurut para Astronom perputaran ini merupakan akibat dari adanya gaya tarik menarik antara gaya gravitasi matahari dengan gaya gravitasi bumi dan perputaran itu menjadi tanda yang menunjukkan masa-masa yang tetap dan hari-hari dan tahun-tahun, Rotasi yang dimaksud oleh para Astronom realitanya sesuai dengan apa yang dikatakan Alkitab dan itu terjadi bukan satu kebetulan tetapi karena memang demikian Firman Tuhan sehingga yang ada itu terjadi sesuai dengan yang dikehendaki Tuhan pada ciptaan-Nya. Pandangan ini sesuai dengan apa yang dituliskan dalam Alkitab. Berfirmanlah Allah: "Jadilah benda-benda penerang pada cakrawala untuk memisahkan siang dari malam. Biarlah benda-benda penerang itu menjadi tanda yang menunjukkan masa-masa yang tetap dan hari-hari dan tahun-tahun, dan sebagai penerang pada cakrawala biarlah benda-benda itu menerangi bumi." Dan jadilah demikian (Kej.1:14-15).

Dalam Kejadian 1:16-18 disebutkan Allah menjadikan kedua benda penerang yang besar itu, yakni yang lebih besar untuk menguasai siang, ini dimaksudkan adalah salah satu bintang yang paling dekat dari bumi yakni matahari. Sedangkan dan yang lebih kecil untuk menguasai malam ini adalah planet dari matahari yakni bulan, semua itu ada di cakrawala untuk menerangi bumi. Dalam ayat 16 disebutkan: maka Allah menjadikan kedua benda penerang yang besar itu, narasi ini satu informasi dari maksud Musa menjelaskan bahwa kedua benda besar itu (matahari dan bulan), menjadi penentu masa-masa yang tetap dan hari-hari dan tahun-tahun dan bukan untuk menjelaskan bahwa kedua alat penerang itu diciptakan pada masa yang berbeda dengan bintangbintang yang lainnya, karena kedua alat penerang itu termasuk bagian yang diciptakan seperti yang terdapat Kejadian 1:14, semua alat-alat penerang itu dicipta pada hari keempat (Kej.1:19).

\section{Kejadian 1:20-23}

Semua ada karena DIA, binatang air binatang darat juga unggas adalah ciptaan Tuhan. Menurut Kejadian 1:20 bahwa binatang air dan unggas lebih dulu diciptakan Tuhan dari pada binatang darat karena binatang air dicipta Tuhan pada hari keenam, 
dan penciptaan itu satu masa dengan penciptaan manusia (Kej.1:24), dengan demikan sesuai ayat tersebut binatang air dan unggas lebih tua dari binatang darat. Hendaklah dalam air berkeriapan makhluk yang hidup, dan hendaklah burung beterbangan di atas bumi melintasi cakrawala. (Kej.1:20). Demikian Firman yang diterima Musa dari Tuhan sebagai informasi asal mula adanya segala jenis makhluk yang hidup, ternak dan binatang melata dan segala jenis binatang liar. Iini sekaligus untuk memberitahukan bahwa segala yang ada itu ada pencipta-Nya.

Bila diperhatikan dengan baik Kejadian 1:20 dan 24 digunakan dengan kata yang sama disebutkan wa'yyomer Elohiym totse' ha'arets, dan penekanannya ada pada kata totse dibentuk sebagai kata kerja hiphil imperfect, yang berarti "hendaklah bumi atau bumi akan mengeluarkan", berbeda dengan ayat-ayat lain yang biasa digunakan dengan kata "yhiy" (jadilah) (Kej.1:3,6,14). Ayat tersebut memberi interpretasi bahwa bumi akan berpartisifasi dalam kelanjutan hidup binatang yang diciptakan, tentu hal itu dapat diartikan setelah binatang diciptakan akan ada terbentuk keragaman jenis binatang adalah hasil siklus alam membentuknya (kawin silang) sehingga pada gilirannya dapat dilihat bahwa baik binatang laut binatang darat maupun unggas sangat beraneka ragama jenis ukuran maupun bentuknya. Beda dengan kelanjutan perkembangan manusia yang pada dasarnya dicipta menggunakan kata sama dan ukurannya tidak terlalu tajam perbedaannya. Hal inilah yang dimaksud totse' pada penciptaan pada binatang air, darat dan unggas dan bumi akan mengeluarkan (berpartisivasi) membentuk keragaman dari binatang-binatang tersebut.

\section{Binatang Purba}

Maka Allah menciptakan binatang-binatang laut yang besar... (Kej.1:21). Ayat ini memberi informasi bahwa binatang ada bukan ada sendiri tetapi ada penciptanya yaitu Tuhan. Kejadian 1:21 juga memberi makna bahwa binatang air dan unggas berbeda masa penciptaannya dengan binatang darat. Informasi itu dapat diketahui karena pada ayat selanjutnya, Hendaklah bumi mengeluarkan segala jenis makhluk yang hidup, ternak dan binatang melata dan segala jenis binatang liar (Kej.1:24). Binatang air dan unggas di udara dicipta masa penciptaan kelima sedangkan binatang darat di cipta satu masa dengan penciptaan manusia yaitu masa penciptaan keenam (ayat 24-26).

Dalam Kejadian 1:21 digunakan kata hattanniynim haggdoliym tentu keberadaan mahluk tersebut dimaksudkan yang hidup sesuai ayat 20 yaitu mahluk hammayim (air laut), hal itu sangat memberikan perbedaan dengan yang dimaksud mahluk yang ada 
pada ayat 24 yaitu bintang darat. Meski masa penciptaan binatang darat dengan manusia dicipta pada masa penciptaan keenam, bukan berarti penciptaan itu bersamaan dilakukan. Hal itu ditandai karena pada ayat 25 pada penciptaan binatang ternak dan pada ayat 26 ada susulan kata hubung waw sebagai awalan pada kata amar. Jadi kehadiran kata hubung waw dihadapan kata amar menjadi "wayy'omer" memberi interpretasi satu alur cerita tetapi beda peristiwa. Tanda hubung waw yang menandai ada perbedaan durasi antara Kejadian 25 dan Kejadian 26.

Penciptaan binatang dan manusia meski pada satu masa namun durasi itu dapat diinterpretasikan satu hari, 100 tahun, 1000 tahun, 100 juta tahun dan dapat juga milliar juta tahun atau lebih. Jarak durasi peristiwa penciptaan binatang darat dengan penciptaan manusia sulit menyimpulkannya apakah itu 1 hari atau 500 juta tahun, meski dalam terjemahan diartikan satu hari bukan berarti penciptaan itu terjadi dalam 1 masa yaitu 1 x 24 jam. Jika dipinjam ayat pendukung lain satu hari/masa bagi Tuhan sama dengan 1 waktu yang tak terbatas bagi manusia, istilah ini digunakan dengan kata 1000 tahun, Akan tetapi, saudara-saudaraku yang kekasih, yang satu ini tidak boleh kamu lupakan, yaitu, bahwa di hadapan Tuhan satu hari sama seperti seribu tahun dan seribu tahun sama seperti satu hari. (2Pet.3:8). Tentu maksud ayat tersebut bukanlah seperti hitungan millinium tetapi seribu artinya tahun yang panjang /tak terbatas.

Alkitab tidak mencantumkan durasi antara penciptaan binatang dengan penciptaan manusia, itu karena maksud dari penciptaan itu adalah suatu informasi apa yang telah ada bukan sendirinya ada tetapi ada penciptanya. Meski tidak ada tertulis sebagai rujukan kedua ciptaan tersebut sebagai laporan pengetahuan, bukan berarti Alkitab tidak dapat menerima penelitian para Arkeolog. Setelah mereka melakukan penelitian dan mengatakan bahwa binatang purba usianya sudah ratusan juta tahun. Misalnya binatang Dinosaurus yang hidup dari priode Trias yang dikelompokkan spesies yang pernah hidup di jagat raya ini dan hidup sekitar 230 juta tahun yang lalu. Hal ini dapat dijadikan satu apoleget bahwa apa yang telah ada tertulis dalam Alkitab adalah kebenaran yang dapat ditinjau dari sisi ilmu pengetahuan sekuler, karena kebenaran Alkitab semua datang dari Firman dan kebenaran itu harus kita terima sebagai kebenaran iman dan diaplikasikan dalam kehidupan umum.

Adanya perdebatan antara kebenaran Sains dan Alkitab, para arkelog bersikukuh dengan hasil penelitiannya sementara dari pihak teolog bertahan dari sisi imannya sehingga kedua kubu ini seakan tidak ada titik temunya. Kebenaran dari sisi ilmu 
pengetahuan sekuler dan pengetahuan iman (Alkitab) mengenai adanya binatang purba seperti yang dimaksud diatas dapat sejalan apa bila pemahaman terhadap Alkitab tidak kaku dan memahami maksud dari penulis kitab. Itu tentu tidak dapat lepas dari pengetahuan tata bahasa yang digunakan Alkitab sebagai rujukan. Jika cara kekakuan itu masih tetap dipertahankan maka sesungguhnya para teolog itu sendirilah yang telah "mencelakakan" isi Alkitab, maka dibutuhkan satu pembenahan hermeneutik sehingga interpretasinya ada pada jalur yang tepat.

\section{Yunus di Perut Ikan}

"Maka Allah menciptakan binatang-binatang laut yang besar dan segala jenis makhluk hidup yang bergerak, yang berkeriapan dalam air, dan segala jenis burung yang bersayap. Allah melihat bahwa semuanya itu baik" (Kej.1:21). Pada gilirannya ada binatang jinak akan menjadi ternak sedangkan binatang liar menjadi binatang buruan. Ada binatang besar (Paus/hiu) dan buas dan ada binatang kecil (planton) dan semua itu dalam jangka yang panjang dan beranak-pinak jumlah binatang-binatang tersebut ada dengan jumlah yang banyak.

Adanya ikan besar hidup dilaut adalah fakta dan hal tersebut sudah berita umum diketahui semua kalangan usia, baik dari usia anak maupun manula. Informasi tersebut banyak diketahui dari beberapa peneliti media informasi yang sangat luas dapat menolong memiliki pengetahuan itu. Adanya keberadaan ikan besar di laut bukan sendirinya ada tetapi ada penciptanya yaitu Tuhan sebagai mana tertulis dengan jelas dalam Kejadian 1:21 disebutkan wayybra' Elohiym 'et-hattanniynim haggdoliym "dan diciptakan Tuhan-lah binatang-binatang laut yang besar". Kata hattanniynim yang berarti binatang-bintang atau mahluk. Pada gilirannya binatang air yang sangat besar itu disebutkan ikan Paus (ikan besar dari yang terbesar).

Meski ada beberapa catatan mengatakan Paus bukanlah sejenis ikan, hal itu dapat diterima dengan baik dan netralnya disebutkan mahluk besar yang ada dalam air adalah kelompok binatang mamalia, yaitu hewan/binatang vertebrata (dicirikan oleh adanya kelenjer susu, yang pada betinanya menghasilkan susu sebagai sumber makanan anaknya).

History yang dimaksud ikan besar dapat dilihat dari pengalaman Yunus seorang abdi Allah yang terdapat dalam kitab Perjanjian Lama tepatnya dalam kitab Yunus. Disebutkan Yunus memiliki pengalaman masuk dalam perut ikan besar. Apa yang dialami oleh Yunus adalah fakta dan bukan fiktif. Para peneliti kebenaran Alkitab telah 
banyak telah memberi sumbangan dari hasil penelitiannya, dan dapat membuktikan bahwa pengalaman Yunus kebenarannya dapat ditinjau dari sisi ilmu pengetahuan umum. ....Yunus tinggal di dalam perut ikan itu tiga hari tiga malam lamanya (Yun.1:17). Kronologis apa yang dialami oleh Yunus anak Amitai agar pergi ke kota Niniwe untuk memberitakan Injil. Allah menginginkan agar kota Niniwe melakukan pertobatan, jika tidak maka kota itu akan di hancurkan. "Bangunlah, pergilah ke Niniwe, kota yang besar itu, berserulah terhadap mereka, karena kejahatannya telah sampai kepada-Ku (Yunus 1:2). Yunuspun berangkat tetapi bukan ke tujuan sebagaimana yang dimaksud Tuhan pada dirinya. Yunus melarikan diri ke Tarsis (ayat 3) dengan naik kapal dari Yafo. Tuhan sangat murka kepada Yunus karena ia mencoba lari dari apa yang Tuhan maksudkan dalam hidupnya. Lalu Tuhan menurunkan badai sehingga semua orang-orang yang ada dalam kapal tersebut ketakutan. Dalam ketakutan itu Yunus tertidur dengan pulasnya. Sang nahkoda melihat Yunus tertidur pulas maka sang nahkoda berkata kepadanya: "Bagaimana mungkin engkau tidur begitu nyenyak? Bangunlah, berserulah kepada Allahmu, barangkali Allah itu akan mengindahkan kita, sehingga kita tidak binasa. Yunus tidak mempedulikan perkataan Nahkoda maka orang-orang yang ada dalam perahu itu melakukan undi, harapannya mereka melalui undi itu akan dapat diketahui siapa yang menjadi penyebab badai mengamuk itu. Pemahaman mereka ada penyebab mengapa badai itu mengamuk, mereka percayai ada sesuatu yang salah di antara mereka.

Ketika mereka melakukan undi Yunuslah yang kena undi, Berkatalah mereka kepadanya: Apa pekerjaanmu dan dari mana engkau datang, apa negerimu dan dari bangsa manakah engkau?" Sahutnya kepada mereka: "Aku seorang Ibrani; aku takut akan TUHAN, Allah yang empunya langit, yang telah menjadikan lautan dan daratan." Orang-orang itu menjadi sangat takut, lalu berkata kepadanya: "Apa yang telah kauperbuat?" Akan kami apakan engkau, supaya laut menjadi reda dan tidak menyerang kami lagi, sebab laut semakin bergelora." Sahutnya kepada mereka: "Angkatlah aku, campakkanlah aku ke dalam laut, maka laut akan menjadi reda dan tidak menyerang kamu lagi. Sebab aku tahu, bahwa karena akulah badai besar ini menyerang kamu" (Yun.8:12) Kemudian mereka mengangkat Yunus, lalu mencampakkannya ke dalam laut, dan laut berhenti mengamuk (1:15). Atas penentuan TUHAN datanglah seekor ikan besar yang menelan Yunus; dan Yunus tinggal di dalam perut ikan itu tiga hari tiga malam lamanya (ayat 17) 
Menanggapi apa yang tertulis dalam Alkitab mengenai Yunus ada diperut ikan kaum liberal seringkali mencoba mengatasi masalah ini dengan berkata bahwa cerita tentang Yunus hanyalah sebuah kiasan dan tidak dimaksudkan untuk dipahami sebagai kebenaran sejarah. Kisah Yunus bukankah suatu kiasan atau perumpamaan serta cerita simbolik lainnya, tetapi sejarah yang nyata. Adapun alasan-alasannya sebagai bukti kisah Yunus bukanlah simbolik, kiasan atau fiktif:

Pertama, Yunus adalah benar seorang nabi yang juga disebutkan dalam 2Raja 14:25. Tidak seorangpun dari orang Yahudi atau orang Kristen terdahulu yang meragukan otentik dan sejarah dari buku Yunus dan ceritanya.

Kedua, Banyak saksi dan ada dialog yang terlibat dalam peristiwa ketika Yunus di lemparkan ke dalam Laut, (Yun.1:10) Orang-orang itu menjadi sangat takut, lalu berkata kepadanya: apa yang telah kau perbuat? "akan kami apakan engkau, supaya laut menjadi reda dan tidak menyerang kami lagi, sebab laut semakin bergelora"(Ayat 10-1).

Ketiga, Yesus membenarkan Peristiwa itu, sebab seperti Yunus tinggal di dalam perut ikan tiga hari tiga malam, demikian juga Anak Manusia akan tinggal di dalam rahim bumi tiga hari tiga malam (Mat.12:40), sebab seperti Yunus menjadi tanda untuk orang-orang Niniwe, demikian pulalah Anak Manusia akan menjadi tanda untuk angkatan ini (Luk.11:30).

Keempat, para ahli sejarah telah memberikan hipotesis pada peristiwa Yunus dengan pertanyaan-pertanyaan, misalnya, bagaimana ukuran rahang ikan besar ketika menelan Yunus. bagimana ruang perut ikan kali besar tubuh Yunus, Bagimana situasi perut ikan (untuk pernafasan) selama Yunus dalam perut ikan besar.

Oktober 2010 berita harian Amerika ada menuliskan menemukan binatang terbesar yang pernah ada di dunia yang sampai sekarang masih ada hidup yaitu ikan paus biru. Panjang binatang/hewan ikan paus ini kurang lebih sekitar 33 meter yang mempunyai berat hingga mencapai 180 -an ton, panjang mulut 4,9 meter, tinggi 3,7 Meter, lebar 2,4 meter sungguh ukuran yang sangat spektakuler. Bila dilihat dari apa yang diutarakan oleh berita harian itu maka sangat dimungkinkan Yunus masuk ke dalam perut ikan tidaklah sulit, dan tidak perlu terlebih dahulu binatang besar itu meremukkan tubuh Yunus, namun dengan menelan saja Yunus dapat masuk langsung dengan mudahnya masuk ke dalam perut binatang besar itu. maka dengan hitungan yang dimaksud di atas dapat diperkirakan sebuah sampanpun dapat dengan mudahnya masuk ke dalam mulut (ditelan) binatang laut itu. 
Rintihan dan doa Yunus dapat dibayangkan betapa menderitanya selama diperut binatang air yang besar itu:

"Berdoalah Yunus kepada TUHAN, Allahnya, dari dalam perut ikan itu, katanya: "Dalam kesusahanku aku berseru kepada TUHAN, dan Ia menjawab aku, dari tengah-tengah dunia orang mati aku berteriak, dan Kaudengarkan suaraku. Telah Kaulemparkan aku ke tempat yang dalam, ke pusat lautan, lalu aku terangkum oleh arus air; segala gelora dan gelombang-Mu melingkupi aku. Dan aku berkata: telah terusir aku dari hadapan mata-Mu. Mungkinkah aku memandang lagi bait$\mathrm{Mu}$ yang kudus? Segala air telah mengepung aku, mengancam nyawaku; samudera raya merangkum aku; lumut lautan membelit kepalaku di dasar gunung-gunung. Aku tenggelam ke dasar bumi; pintunya terpalang di belakangku untuk selama-lamanya. Ketika itulah Engkau naikkan nyawaku dari dalam liang kubur, ya TUHAN, Allahku"(2:1-6).

Dalam kesesakan Yunus, ia berdoa kepada Tuhan, dan Tuhan mendengar doanya, lalu Tuhan memerintahkan binatang besar itu untuk memuntahkan Yunus ke darat, akhirnya Yunuspun selamat, Lalu berfirmanlah TUHAN kepada ikan itu, dan ikan itu pun memuntahkan Yunus ke darat (2:10). Dari pemaparan di atas dapat diberi kesimpulan bahwa kebenaran Yunus diperut ikan bukanlah fiktif tetapi fakta.

Meski beberapa pandangan mengatakan ikan besar itu bukan termasuk binatang laut dengan alasan memamah biak tapi kenyataannya ikan tersebut tidak dapat bertahan hidup di darat. Sementara dalam Kejadian 1:21 segala jenis makhluk hidup yang bergerak, yang berkeriapan dalam air, maka dengan dimikian ikan besar itu termasuk binatang laut yang dicipta pada hari kelima (band.Kej.1:23).

Kejadian 1:24-25

Binatang-binatang yang ada di udara dan di dalam laut dicipta pada hari yang kelima. Tetapi untuk binatang darat dicipta pada hari keenam. Binatang darat terlebih dahulu dicipta dari penciptaan manusia, sebagaiamana friman Tuhan menjelaskan: "Hendaklah bumi mengeluarkan segala jenis makhluk yang hidup, ternak dan binatang melata dan segala jenis binatang liar. Allah menjadikan segala jenis binatang liar dan segala jenis ternak dan segala jenis binatang melata di muka bumi. (Kej.1:24-25). Dari ayat di atas dapat diberi kesimpulan bahwa binatang darat lebih tua dari pada manusia. Batas penciptaan binatang darat dengan penciptaan manusia ada pada pada ayat 25 . Durasa penciptaan antara binatang darat dan manusia tidak dapat ditentukan. Dengan tidak adanya diberitahukan jarak tempo pada kedua ciptaan itu maka tidak dapat diketahui apakah jarak kedua ciptaan itu selisih 1menit, 1 jam, 1000 tahun atau 1 triliun 
tahun, karena diakhir ayat 25 ditandai dengan silluq sementara di awal 26 ada kata hubung waw.

Dengan adanya kedua tanda baca silluq dan kata hubung waw, maka kedua ayat tersebut dapat diinterpretasikan, Pertama, Musa ingin memberitahukan kepada pembaca kitab Kejadian bahwa penciptaan binatang darat dan penciptaan manusia tidaklah sekaligus dalam satu waktu. Kedua, sebagai rentetan satu informasi tetapi beda peristiwa.

\section{Kejadian 1:26-30}

Peristiwa penciptaan bagi umat Israel tidaklah semata-mata merupakan suatu pokok yang penting dan berharga tetapi lebih-lebih merupakan suatu pokok kebanggaan, penghiburan dan pengakuan percaya bahwa dalam kitab suci merekalah (Taurat) merupakan menjadi panduan pengetahuan asal mula manusia ada dituliskan. Tidak dapat dielakkan oleh kepercayaan lain maupun ilmu pengetahuan, percaya bahwa kitab suci Israel menjadi dasar pengetahuan dari mana asal munusia itu ada.

Dari kitab Taurat itulah akar pengetahuan kata manusia adalah (baca: Adam), dan di dalam Alkitab kata itu digunakan sebanyak 535 kali. Pertama sekali terdapat dalam kitab Kejadian 1:26 dan yang terakhir dalam Alkitab terjemahan Alkitab bahasa Indonesia terdapat dalam Maleakhi 3:8, sedangkan dalam Alkitab yang menggunakan bahasa Ibrani kata manusia ada terdapat dalam 2 Tawarikh 32:19.

Setelah Tuhan Allah menciptakan segala sesuatu maka selanjutnya Allah menciptakan manusia. Dalam Kejadian 1:26 didahului dengan kalimat: wayy'omer elohim dan Tuhan berfirman. Anak kalimat ini memberi keterangan bahwa Musa yang dipercayakan menuliskan ayat, wayy'omer elohim (dan Allah berfirman), dituliskan dan didahului dengan kata hubung waw, ini memberi penjelasan bahwa kata hubung waw memberi keterangan bahwa ayat tersebut masih berhubungan dengan ayat sebelumnya. Namun peristiwa masa antara ayat 25 dan ayat 26 tidak dapat dituntukan, artinya ayat 26 adalah informasi apa yang dilakukan Allah setelah menciptakan segala yang ada. ayat 25 dan 26 ini merupakan penggalan informasi peristiwa yang dilakukan Allah dan segala yang telah ada diciptakan sebagai persiapan kebutuhan dan perlengkapan bagi manusia.

Selanjutkan, "nayase ada bnyalmenu wyirddu bidgat hayyim" yang berarti: dibentuklah manusia menurut gambar rupa kita, dan kita akan berkuasa atas ikan-ikan di laut). Allah menciptakan manusia dan memberi ketetapkan bahwa manusia akan lebih berkuasa "wyirddu” dari segala mahluk hidup yang pernah diciptaan yang ada di 
bumi. Karena itu pada kenyataan yang ada, sebuas apapun atau sebesar apapun binatang ikan-ikan di laut dan burung-burung di udara, ternak dan atas seluruh bumi dan segala binatang melata yang merayap, manusia dapat menundukkannya (berkuasa) atau menaklukkannya.

Frase kita yang dimaksud dalam ayat terjemahan itu adalah Musa dan pembaca kitab. Musa ingin menjelaskan bahwa manusia pertama yang telah diciptakan Allah sama seperti kita, memiliki rupa yang sama. bila mereka dapat berkuasa atas ikan-ikan di laut dan burung-burung di udara dan atas ternak dan atas seluruh bumi dan atas segala binatang melata yang merayap di bumi, kitapun sama seperti manusia pertama. Kesamaan itu dapat diartikan bahwa kita saat ini bukanlah hasil evolusi dari mahluk yang lain.

Penekanan kata yang perlu diperhatikan dalam Kejadian 1:26 ini ada pada kata "nayase". Ini merupakan kata kerja yang bertindak pada satu kegiatan yang akan terjadi yang dikenal dengan kata imperfect dalam konteks kata kerja khohortatif yang searti dengan kata kata kerja imperative dan diartikan dengan kata: lah, mari, silahkan, sekiranya, dan lain-lain. adapun yang dimaksud kata nayase adalah kata kerja imperfect karena ditandai dengan awalan na, dan kata tersebut memiliki akar kata yasa yang berarti: bentuk (make). Nayase hurufiahnya: akan dibentuklah. Kata akan dalam terjemahannya pada kata kerja sering tidak diterjemahkan, namun bagi yang mengucapkan dan yang mendengar mengerti di dalam kata yang dimaksud ada terkandung kata akan.

Jadi kata, 'nayase adam bnyalmenu kidmutenu' yang berarti: (akan) dibentuklah manusia dalam (menurut) rupa seperti gambar kita. Untuk perjelasan kata dalam (menurut) rupa dan seperti gambar kita, Musa menjelaskan pada ayat selanjutnya (pada ayat 27). Di dalam ayat 27 diinformasikan bahwa yang dimaksud menurut rupa gambar kita, adalah rupa gambar Allah.

\section{Kejadian 1:27}

Maka Allah menciptakan manusia itu menurut gambar-Nya, menurut gambar Allah diciptakan-Nya dia; laki-laki dan perempuan diciptakan-Nya mereka. Allah menciptakan manusia sangat sempurna, tidak seperti ternak dan binatang lainnya karena dalam ayat ini ada disebutkan: (bnyallemo bnyelel Elohim) - menurut gambarNya, menurut gambar Allah- LAI), dan ayat ini juga memberi keterangan bahwa Kejadian 1:26 priode penciptaan manusia itu sudah komplit, arti kata komplit bahwa 
pasangan (wanita dan pria) manusia itu sudah ada, ini memperjelas manusia diciptakan pada hari keenam.

Dalam ayat 27 ini ada dua kali disebutkan, Pertama: bara ito zakar unqeba yang berarti: Ia ciptakan jantan (pria) dan juga betina (wanita). Kedua, bara' ittam yang berarti: diciptakan mereka. Frase ini mengacu kepada manusia pertama yang diciptakan Allah. Pria dan wanita dicipta serupa dan segambar dengan Allah, dengan ini maka diketahui bahwa antara pria dan wanita tidak ada ada diskriminasi dihadaan Allah, pria dan wanita sama bagiNya.

Di dalam ayat ini juga dijelaskan bahwa laki-laki dan perempuan sudah diciptakan, dan praktek penciptaan laki-laki dijelaskan dalam Kejadian 2:7, sedangkan untuk perempuan ada dijelaskan dalam Kejadian 2:21-22.

\section{Kejadian 1:28-31}

Allah memberkati mereka, lalu Allah berfirman kepada mereka: "Beranakcuculah dan bertambah banyak; Setelah Allah menciptakan manusia, maka Allah memberkati (mempersatukan menjadi suami istri), Allah memberikan perintah agar manusia itu beranakcuculah dan bertambah banyak; memenuhi bumi dan menaklukkanlah segala yang ada, berkuasalah atas ikan-ikan di laut dan burung-burung di udara dan atas segala binatang yang merayap di bumi. Allah menciptakan manusia tidak hanya memberikan pengetahuan (kuasa), tetapi Allah juga memberikan seluruh ciptaan yang ada seperti tumbuh-tumbuhan yang berbiji di seluruh bumi dan segala pohon-pohonan yang buahnya berbiji untuk makanan mereka (Kej.1:29). Allah juga memberikan segala binatang di bumi dan segala burung di udara dan segala yang merayap di bumi segala tumbuh-tumbuhan hijau. Semua Allah berikan untuk kebutuhan maanusia yang diciptakan itu (Kej.1:30). Semua yang diciptakan Tuhan sempurna adanya dan semua terjadi sesuai yang Tuhan mau. Enam hari lamanya Tuhan menciptakan segala sesuatu (band.Kej.1:31). 


\section{Teologi}

Kejadian 1:1 menjadi pengakuan bangsa Israel sekaligus kebanggaan mereka bahwa dalam kitab Taurat ada dituliskan awal mula segala yang ada. Ayat tersebut adalah ayat yang sangat tua dari segala tulisan yang ada yang menginformasikan keberadaan segala yang ada. Melalui ayat-ayat itu dapat diambil satu pengetahuan bahwa segala yang ada bukan sendiri ada tetapi ada Penciptanya. Demikianlah riwayat langit dan bumi pada waktu diciptakan. Ketika TUHAN Allah menjadikan bumi dan langit (Kej.2:4).

Bangsa Israel menyakini ini penuh bahwa Allah yang telah menciptakan langit dan bumi beserta isinya. Hal ini dimasud dari pihak Israel sendiri tidak menolak keberadaan Tora itu sebagaimana keutuhan isinya sebagai informasi penciptaan yang telah diciptakan Allah. Isrel sangat menyakini bahwa sang pencipta itu adalah YHWH Allah Israel dan sebagai junjungan mereka. Satu kebanggaan bagi Israel bahwa segala sesuatu yang telah ada, ada diiformasikan di dalam kitab kebanggan mereka yaitu Tora/Taurat, Ayat tersebut dari berbagai kepercayaan menggunakan sebagai ayat acuan bahwa segala sesuatu ada penciptanya.

Pentingnya pemahaman dalam hal ini:

Pertama, ayat ini memberi satu informasi penting bagi pengetahuan satu-satunya kitab yang telah memberi pengetahuan bagaimana segala sesuatu itu ada dan ada bukan sendirinya ada tetapi ada penciptanya.

Kedua, Agar dapat memahami betapa besar dan agung karya Allah. Pengenalan terhadap Kejadian 1 merupakan pengetahuan betapa dasyatnya Sang pencipta telah menciptakan yang tak dapat dilakukan dan dipikirkan oleh oleh teknologi manusia. Allah mengadakan ciptaan itu dari bahan baku yang tidak ada menjadi ada dan diciptakan melalui Firman-Nya.

Ketiga. Melalui penciptaan itu manusia dapat menyadari bahwa penciptanya bukan ada melalui proses evolusi. Banyak teory-teory yang telah dimunculkan bagaimana proses yang ada melalui evolusi, namun teori itu hanyalah teori semata dan teori itu tak dapat membuktikan bagaimana proses evolusi itu berawal dari yang tidak ada. (band.Kej.2:19).

Keempat. Awal manusia mengenal adanya Allah (sang Pencipta). Segala sesuatu yang telah diciptakan Allah indah dan sempurna adanya. Awal adanya pengetahuan bagi 
manusia bahwa ada yang Maha Pencipta yang telah menciptana segala yang ada. Tidak ada yang mampu seperti Allah menciptakan segala yang telah ada.

Kelima. Awal mengetahui bahwa Allah dan manusia memiliki karakter yang sama (Kej. 1:26). Apa yang dapat dirasakan oleh manusia dapat dirasakan oleh Allah, misalnya manusia itu mahluk social ada rasa cemburu demikian juga Allah memiliki rasa cemburu. Manusia dapat marah demikian juga Allah. Allah menciptakan manusia itu menurut gambar-Nya, menurut gambar Allah diciptakan-Nya dia; laki-laki dan perempuan diciptakan-Nya mereka (Kej.1:27).

\section{Daftar Pustaka}

Strong Exhaustive Concordance of the Bible With

Dictionaries of the Hebrew and Greek Words of the Original With Refrence to the English Words. Grand Rapids: Christian Feritage Publishing Company, 1988.

The Interlinear Hebrew Greek English Bible. Vol. 3

(Psalm 56 - Malachi), Indiana: Asosiated Publishers And Author, 1978.

van Ruler, The Witnes of the Old Testament to Christ, London: Oxford University Press, 1949.

Aron Pick, Dictionary Of Old Testament Word For English Readers, Michigan: Kregel Publication, 1977.

Alkitab Elektronik, AE2000, Versi 2.0.0, Alkitab terjemahan Baru (c) 1974, Lembaga Alkitab Inidonesia (LAI).

Alkitab. Jakarta: Lembaga Alkitab Indonesia, 1997.

Anton Moeliono dkk, Kamus Besar Bahasa Indonesia, (Jakarta: Balai Pustaka, 1997).

Baker. S.M. Siahaan, A.A. Sitompul, Pengantar Bahasa Ibrani, Jakarta: BPK Gunung Mulia, 2002.

Bakker, F. L. Sejarah Kerajaan Allah. Jil. I. Diterjemahkan oleh K. Siagian. Jakarta: BPK Gunung Mulia, 1990.

Barr, James. Alkitab Di Dunia Modern. Jakarta: BPK Gunung Mulia, 1997.

Baxter J. Sidlow. Menggali Isi Alkitab 1, 2, 3, 4. Jakarta: BPK Gunung Mulia. 1980.

Berkhof, Louis. 2011. Systematic Theology. Jilid 1, Terjemahan, Penerbit Momentum: Jakarta.

C.Barth. Theologia Perjanjian Lama, Jilid Pertama, Jakarta: BPK Gunung Mulia, 1991.

C.C. Caragounis, "Kingdom of God/Heaven. Dictionary of Jesus and the Gospel, Downers Grove: Intervarsity Press, 1992.

Charles C. Ryrie, Buku 1 Teologi Dasar. Yogyakarta: Yayasan Andi. 1986.

D.L.Baker, A.A.Sitompul, Kamus Singkat Ibrani Indonesia, Jakarta: BPK Gunung Mulia, 2001.

D.L.Baker. S.M.Siahaan. A.A.Sitompul. Pengantar Bahasa Ibrani. Jakarta: BPK. Gunung Mulia 2002.

Douglas J.D. dkk, Ensiklopedi Alkitab Masa Kini, jilid I, A-L, Cet. 2, (Jakarta, Yayasan Komunikasi Bina Kasih/ OMF, 1994).

Ecker, Yakob, Hikayat Kitab Suci Perjanjian Lama Kitab Suci Untuk Keluarga. Yogyakarta: Kanasius, 1975.

Erickson J. Millard., Christian theology. Jilid 1 \& 2. Terjemahan, Penerbit Gandum Mas: Malang. 2003. 
F. Brown, S. R.Driver, C. A.Briggs, A Hebrew and English Lexicon of the Old Testament, London: Oxford University Press, 1907.

Free, Joseph P. Arkeologi dan Sejarah Alkitab. Direvisi oleh Howard F. Vos. Malang: Gandum Mas, 1997.

Geoffrey W. Bromiley, D. LITT, D.D., Vol. VI. (Michigan-Grand Rapids: W.M.B. Eerdemans Publishing Company, 1967

Gerhad F. Hasel, Teologi Perjanjian Lama Masalah-masalah Pokok dalam Perdebatan Saat ini. (Edisi Revisis), Malang: Gandum Mas, 2001.

Gering Howard M. Analisa Alkitab. Jakarta:Yayasan Pekabar Injil Immanuel. 1989.

Green, Denis. Pembimbing Pada Pengenalan Perjanjian Lama. Malang: Gandum Mas, 2000.

Green, Jay P. The Interlinear Bible Hebrew Greek English, With Strong's Concordance Numbers Above Each Word. London: Hendrikson Publishers, 1985.

Haag, Herbert. Kamus Alkitab. Ende-NTT: Nusa Indah,1992.

Hartanti, Mary. Biodata Tokoh-tokoh Alkitab Perjanjian Lama Statistik, ringkasan Kronologis \& Theologis. Jakarta: Markus Agung, t.t.

Harun Hadiwijono, Iman Kristen, BPK-Gunung Mulia Henk ten Napel, Kamus Teologi, Inggris -Indonesia.

J.Weingreen, A Practical Grammar for Classical Hebrew, Oxford At the clarendon, 1959.

James Strong, The Interlinear Hebrew Greek English Bible. Vol. 3 (Psalm 56 - Malachi), Indiana: Asosiated Publishers And Author, 1978.

John F. Walvoord, The Kingdom of God in the Old Testament". Bibliotheca Sacra 1982.

John M.Echols, Hassan Shadily, Kamus Indonesia - Inggris An Indonesia - English Dictionary. Jakarta: Gramedia, 1997.

Larry A. Mitchel. A Student's Vocabulary for Biblical Hebrew and Aramic, Grand Rapids: Zondervn, 1984.

McKenzie, A Theology of the Old Testament, New York: Garden City, 1974.

Poerwadamanto, Kamus Besar Bahasa Indonesia.

Prederick D.Bruner, Matthew. A Commentary Matthew 1-12. Vol. Word Publishing Dallas. 1987. London.

S. Wismoady Wahono. Di Sini Kutemukan. Jakarta: BPK Gunung Mulia. 1986.

Soedarmo R, Kamus Istilah Teologi, Cet. 4, Jakarta, BPK. Gunung Mulia, 1989.

Stamp Donald. Alkitab Penuntun Hidup Berkelimpahan. Malang: Gandum Mas. 1994.

Walker. D. F. Konkordansi Alkitab. Cet. 5. Jakarta: BPK. Gunung Mulia. 1999.

Wigram, Goerge V. The Englishman's Hebrew and Chaldee Concordance of the Old Testament Numerically Coded to Strong's Exhustive Concordance. Grand Rapids: Baker Book House, 1980

William L. Holldy, A. Concise Hebrew and Aramic Lexicon of the Old Testament, Grand Rapids: Eerdmans, 1988.

Williamson, G.I., 2012. Westminster Confession Of Faith. Terjemahan, Penerbit Momentum: Jakarta. 